\title{
Pengaruh Ritma Circadian Terhadap Produksi Volatile Sulfur Compounds (VSC) Oral
}

\author{
Supriatno \\ Bagian Ilmu Penyakit Mulut Fakultas Kedokteran Gigi Universitas Gadjah Mada \\ Jl Denta no 1 Sekip Utara Yogyakarta, e-mail: pridentagama_oncolog@yahoo.com
}

\begin{abstract}
ABSTRAK
Volatile sulfur compounds (VSCS) oral dihasilkan dari produk putrifikasi mikroba gas hidrogen sulfida $\left(\mathrm{H}_{2} \mathrm{~S}\right)$, metil merkaptan $\left(\mathrm{CH}_{3} \mathrm{SH}\right)$ dan dimetil sulfida $\left[\left(\mathrm{CH}_{3}\right)_{2} \mathrm{~S}\right]$ yang merupakan gas utama penyebab halitosis. Ritma circadian mempunyai pengaruh terhadap fungsi beberapa organ tubuh termasuk sekresi saliva, produksi hormon, fungsi sistim tubuh, dan aktivitas mikroorganisma. Penelitian bertujuan menguji pengaruh ritma circadian terhadap produksi VSC oral yang diukur menggunakan OralChroma portable.Penelitian dilakukan dengan mengukur gas VSC individu yang sama pada pagi, siang dan malam hari di laboratorium riset terpadu FKG UGM. Hasil pengukuran $\mathrm{H}_{2} \mathrm{~S}, \mathrm{CH}_{3} \mathrm{SH}$ dan $\left(\mathrm{CH}_{3}\right)_{2} \mathrm{~S}$ diuji menggunakan analisis statistik Anava dua jalur dilanjutkan uji LSD dan uji korelasi Pearson dengan derajat kemaknaan 95\%. Hasil penelitian menunjukkan terdapat perbedaan yang sangat bermakna antara produksi gas $\mathrm{H}_{2} \mathrm{~S}, \mathrm{CH}_{3} \mathrm{SH}$ dan $\left(\mathrm{CH}_{3}\right)_{2} \mathrm{~S}$ dengan waktu pengukuran (efek circadian) $(\mathrm{p}=0,000)$. Perbedaan sangat bermakna diketahui pula pada pengukuran gas $\mathrm{H}_{2} \mathrm{~S}$ dan $\left(\mathrm{CH}_{3}\right)_{2} \mathrm{~S}$ antara pagi, siang dan malam $(p=0,01$ dan $p=0,00)$, serta pengukuran gas $\mathrm{CH}_{3} \mathrm{SH}$ siang dan malam $(\mathrm{p}=0,006)$, tetapi tidak pada $\mathrm{CH}_{3} \mathrm{SH}$ pagi hari $(\mathrm{p}=0,061)$. Produksi gas $\mathrm{H}_{2} \mathrm{~S}$ tertinggi diketahui pada pagi hari (mean 1,198 ng/10 ml, $\mathrm{CH}_{3} \mathrm{SH}$ pada malam hari (mean 0,099 ng/10 ml), dan $\left(\mathrm{CH}_{3}\right)_{2} \mathrm{~S}$ pada siang hari (mean 1,216 ng/10 ml). Kekuatan hubungan pengukuran antara ke tiga gas dengan efek circadian diketahui sebesar $\mathrm{r}=0,738$. Disimpulkan bahwa ritma circadian berpengaruh terhadap produksi VSCS oral. Produksi gas $\mathrm{H}_{2} \mathrm{~S}$ dan $\left(\mathrm{CH}_{3}\right)_{2} \mathrm{~S}$ berbeda antara pagi, siang dan malam hari, sedangkan produksi gas $\mathrm{CH}_{3} \mathrm{SH}$ berbeda hanya pengukuran siang dan malam hari. Produksi gas $\mathrm{H}_{2} \mathrm{~S}$ tertinggi diketahui pada pagi hari, gas $\mathrm{CH}_{3} \mathrm{SH}$ pada malam hari, dan gas $\left(\mathrm{CH}_{3}\right)_{2} \mathrm{~S}$ pada siang hari. Maj Ked Gi. Juni 2013; 20(1): 14 - 20.
\end{abstract}

Kata kunci: VSC, halitosis, ritma circadian, OralChroma

ABSTRACT: The Effect Of Circadian Rhythm To Oral Volatile Sulfur Compounds Production. Oral volatile sulfur compound (VSC) is produced from microbial purification of hydrogen sulfide $\left(\mathrm{H}_{2} \mathrm{~S}\right)$, methyl mercaptan $\left(\mathrm{CH}_{3} \mathrm{SH}\right)$ and dimethyl sulfide $\left[\left(\mathrm{CH}_{3}\right)_{2} \mathrm{~S}\right]$ gases. They are the main gases that cause halitosis. Circadian rhythm influenced the function of several organs of the human body including salivary secretion, hormone production, the body's systems function, and activity of microorganisms. The purpose of this research is to examine the influence of circadian rhythm to oral VSC production measured by using a portable Oral Chroma. The research was carried-out by measuring the individual VSC gases in the morning, afternoon and evening at the integrated research laboratory, Faculty of Dentistry, UGM. Gases of $\mathrm{H}_{2} \mathrm{~S}, \mathrm{CH}_{3} \mathrm{SH}$ and $\left(\mathrm{CH}_{3}\right)_{2} \mathrm{~S}$ were tested by two-way ANOVA followed by Post-hoc LSD and Pearson correlation test with $95 \%$ significance level. The results showed the positive significant differences among the production of $\mathrm{H}_{2} \mathrm{~S}, \mathrm{CH}_{3} \mathrm{SH}$ and $\left(\mathrm{CH}_{3}\right)_{2} \mathrm{~S}$ with circadian time $(p=0.000)$. Highly significant difference was also detected in amount of $\mathrm{H}_{2} \mathrm{~S}$ and $\left(\mathrm{CH}_{3}\right)_{2} \mathrm{~S}$ gases in the morning, afternoon and evening ( $\left(\mathrm{p}=0.01\right.$ and $p=0.00$ ), as well as the amount of $\mathrm{CH}_{3} \mathrm{SH}$ gas in the afternoon and night $(p=0.006)$, but not in amount of $\mathrm{CH}_{3} \mathrm{SH}$ gas in the morning $(p=0.061)$. The highest production of $\mathrm{H}_{2} \mathrm{~S}$ gas was known in the morning (mean $1.198 \mathrm{ng} / 10 \mathrm{ml}$ ), $\mathrm{CH}_{3} \mathrm{SH}$ gas was detected in the night (mean $0.099 \mathrm{ng} / 10 \mathrm{ml}$ ), and $\left(\mathrm{CH}_{3}\right)_{2} \mathrm{~S}$ gas was observed in the afternoon (mean $1.216 \mathrm{ng} / 10 \mathrm{ml})$. The strength of relationship among amount of three gases with circadian effects was $r=0.738$. It is concluded that circadian rhythm markedly influences the production of oral VSCs. $\mathrm{H}_{2} \mathrm{~S}$ and $\left(\mathrm{CH}_{3}\right)_{2} \mathrm{~S}$ gases production were significantly different among in the morning, afternoon and evening. However, amount of $\mathrm{CH}_{3} \mathrm{SH}$ gas production was significantly different only in the afternoon and the night. The highest gas production of $\mathrm{H}_{2} \mathrm{~S}, \mathrm{CH}_{3} \mathrm{SH}$, and $\left(\mathrm{CH}_{3}\right)_{2} \mathrm{~S}$ was observed in the morning, in the night, and in the afternoon, respectively.

Maj Ked Gi. Juni 2013; 20(1): 14 - 20.

Keywords: VSC, halitosis, circadian rhythm, oral chroma 


\section{PENDAHULUAN}

Halitosis merupakan masalah yang sering ditemukan di masyarakat dan umumnya berhubungan dengan kondisi oral seperti kondisi kebersihan mulut yang buruk dan kondisi periodontal. ${ }^{1}$ Halitosis dihasilkan dari asam amino produk metabolisme mikroba dalam debris lokal. ${ }^{2}$ Terdapat beberapa senyawa utama yang berkontribusi langsung terhadap bau mulut, yang dikenal dengan nama volatile sulfur compounds (VSCs). Kandungan gas utama dalam VSCs termasuk hydrogen sulfide $\left(\mathrm{H}_{2} \mathrm{~S}\right)$, metal merkaptan $\left(\mathrm{CH}_{3} \mathrm{SH}\right)$ dan dimetil sulfida $\left[\left(\mathrm{CH}_{3}\right)_{2} \mathrm{~S}\right]^{3}$. Selain itu, metilamin, dimetilamin, asam propionik, asam butirat, indol, skatol, merkaptol dan kadaverin telah dilaporkan dapat menyebabkan halitosis. ${ }^{4}$ Klasifikasi halitosis menurut Miyazaki dkk., ${ }^{5}$ dan Yaegaki dkk., ${ }^{6}$ dikategorikan sebagai halitosis murni (genuine), pseudohalitosis dan halitophobia. Halitosis murni (genuine) merupakan halitosis yang dapat disubklasifikasi menjadi halitosis fisiologis atau patologis. Halitosis patologis dapat disubklasifikasi menjadi halitosis patologis oral atau non oral, umumnya disebabkan oleh penyakit periodontal. ${ }^{7}$ Jika subyek merasakan bau mulut, tetapi pemeriksaan klinik tidak ditemukan adanya halitosis, maka pertimbangan diagnosisnya adalah psedohalitosis. Subyek dengan pseudohalitosis memerlukan konseling, edukasi dan informasi mengenai keadaan fisik halitosisnya. Halitophobia dikarakteristikkan dengan subyek yang sangat percaya (persistent) bahwa dirinya menderita halitosis walaupun telah dilakukan perawatan dan konseling. Kondisi subyek dengan halitosis patologis non-oral dan halitophobia wajib dirujuk ke dokter spesialis. ${ }^{8}$

Volatile sulfur compound mempunyai konsekuensi patologis sebagai hasil penetrasi dan degradasi metabolisme sel dan sintesis kolagen jaringan oral. ${ }^{9}$ Fraksi volatile mengandung amonia sebagai hasil pembusukan mikroba mulut yang dapat menyebabkan halitosis. Tingkat halitosis subyek dapat ditentukan dengan beberapa metoda termasuk tes organoleptik, gas kromatografi dan monitoring amonia. Sampai saat ini, tes halitosis yang banyak digunakan adalah tes monitoring amonia menggunakan portable machine OraChroma. ${ }^{10}$ Hasil pengukuran produksi gas VSC berbeda antara satu kondisi dengan kondisi lainnya. Level VSC akan berubah drastis sesuai dengan saat makan dan menyikat gigi. Level VSC paling tinggi terdeteksi pada awal pagi/subuh dan secara signifikan berkurang setelah makan, serta akan naik kembali sampai waktu makan berikutnya. ${ }^{11}$

Circadian merupakan proses biologi yang berhubungan dengan ritma tubuh manusia. Ritma tersebut dikendalikan oleh jam circadian (circadian clock) yang telah banyak diobservasi secara luas untuk tumbuhan, hewan, jamur dan bakteri. Istilah circadian berasal dari bahasa Latin: "Circa" yang berarti "sekitarnya", dan "diem atau dies" berarti "hari”. Walaupun ritma circadian bersifat endogen dan berkelanjutan, efek circadian dapat disesuaikan dengan lingkungan lokal. ${ }^{12}$ Ritma circadian mempunyai pola yang jelas pada temperatur tubuh, aktivitas gelombang otak, produksi hormon, regenerasi sel, dan aktivitas biologi lainnya. ${ }^{13}$ Ritma circadian mempunyai pengaruh pula terhadap proses hemodinamik dan fungsi ginjal, ${ }^{14,15}$ hormon endokrin dan paratiroid, ${ }^{16}$ dan aktivitas mikrobiologi oral. ${ }^{17}$ Berdasarkan hasil laporan tersebut, maka pada penelitian ini akan dilakukan pengukuran produksi VSC berdasarkan ritma circadian, yaitu pengukuran pagi hari jam 08.00-09.00 WIB, siang hari jam 13.00-1400 WIB, dan malam hari 18.0019.00 WIB, dengan subyek mahasiswa Fakultas Kedokteran Gigi UGM. Diharapkan hasil penelitian ini dapat menentukan gas-gas apa saja yang tinggi diproduksi pada pagi, siang dan malam hari.

Tujuan penelitian adalah menguji pengaruh ritma circadian terhadap produksi USC oral yang diukur menggunakan alat OralChromaportable.

\section{METODE PENELITIAN}

Sebelum dilaksanakan pengujian terhadap semua sampel penelitian dilakukan pembuatan perijinan penelitian terhadap manusia (ethical clearance) dan surat persetujuan turut berpartisipasi dalam penelitian ini (inform concern). Pengukuran kadar halitosis melalui uji komponen gas VSC $\left(\mathrm{H}_{2} \mathrm{~S} ; \mathrm{CH}_{3} \mathrm{SH} ; \quad\left(\mathrm{CH}_{3}\right)_{2} \mathrm{~S}\right)$ dilakukan menggunakan OralChroma (OralChroma ${ }^{\mathrm{TM}}$ portable; MS-Halimeter E; Interscan Corp, Chatsworth, USA) pada pagi hari 
jam 08.00-09.00 WIB, siang hari jam 13.00-14.00 WIB, dan malam hari jam 19.00-20.00 WIB, pada 35 mahasiswa co-ass yang menjalani stase di bagian Oral Medicine FKC UGM, berumur 20-30 tahun. Mesin OralChroma dinyalakan 30 menit sebelum dilakukan pengujian. Semua subyek penelitian didudukkan dengan santai selama 10 menit sebelum dilakukan pengukuran dan diberi penjelasan jalannya pengukuran. Spuit injeksi plastik tanpa jarum (Terumo, Philiphines) dimasukkan mulut dan didorong ke arah belakang tanpa mengenai lidah dan dinding faring, kemudian spuit injeksi dipegang dengan bibir atas dan bawah. Secara perlahan-lahan tarik ujung spuit untuk mengambil udara di mulut kemudian di hembuskan lagi. Aktivitas ini dilakukan sebanyak tiga kali sebelum mengambil udara/gas di mulut untuk pengukuran. Jika spuit injeksi basah, dikeringkan dengan tissue (See-U, Green value, Suparma Tbk, Surabaya, Indonesia). Selanjutnya spuit injeksi diberi jarum (MS-Halimeter E; Interscan Corp, Chatsworth, USA) dan segera dimasukkan ke dalam inlet mesin OralChroma dengan menekan plunger. Pengukuran gas VSC akan dimulai secara otomatis. Hasil pengukuran kadar VSC akan tampak dilayar monitor setelah 8 menit pengukuran dimulai. Hasil pengukuran gas VSC memakai satuan $\mathrm{ng} / 10 \mathrm{ml}$. Skala pengukuran halitosis menggunakan OralChroma ${ }^{\mathrm{TM}}$ portable menurut Suzuki dkk., ${ }^{18}$ adalah sebagai berikut: Hidrogen sulfida $(\mathrm{H} 2 \mathrm{~S})$ : $>1,5 \mathrm{ng} / 10 \mathrm{ml}$; Metil merkaptan $\left(\mathrm{CH}_{3} \mathrm{SH}\right):>$ 0,5ng/10ml; dan Dimetil sulfida $\left[\left(\mathrm{CH}_{3}\right)_{2} \mathrm{~S}\right]:>0,2 \mathrm{ng} /$ $10 \mathrm{ml}$. Analisis data dilakukan dengan menggunakan uji ANAVA dua jalur dilanjutkan uji Post Hoc (LSD) dengan derajat kemaknaan 95\%. Analisis data dilakukan menggunakan program software SPSS 16.0 (SAS Institute Inc, Cary, NC, USA).

\section{HASIL PENELITIAN}

Hasil penelitian mengenai pengaruh ritma circadian terhadap produk VSCs oral diketahui sebagai berikut. Rerata jumlah gas VSC (satuan ng/10 $\mathrm{ml}$ ) yang diukur pada waktu pagi, siang dan malam hari disajikan dalam Gambar 1.

Gambar 1 menunjukkan rerata produk gas hydrogen sulfida $\left(\mathrm{H}_{2} \mathrm{~S}\right)$ yang terukur dengan alat OralChroma pada waktu pagi hari sebesar 1,199 $\mathrm{ng} / 10 \mathrm{ml}$, siang hari $0,819 \mathrm{ng} / 10 \mathrm{ml}$, dan malam hari terdeteksi 0,395 ng/10 ml. Hasil ini menunjukkan bahwa kadar gas $\mathrm{H}_{2} \mathrm{~S}$ tertinggi diketahui pada pagi hari. Pengukuran rerata kadar gas metil merkaptan $\left(\mathrm{CH}_{3} \mathrm{SH}\right)$ menunjukkan hasil pada pagi hari sebesar

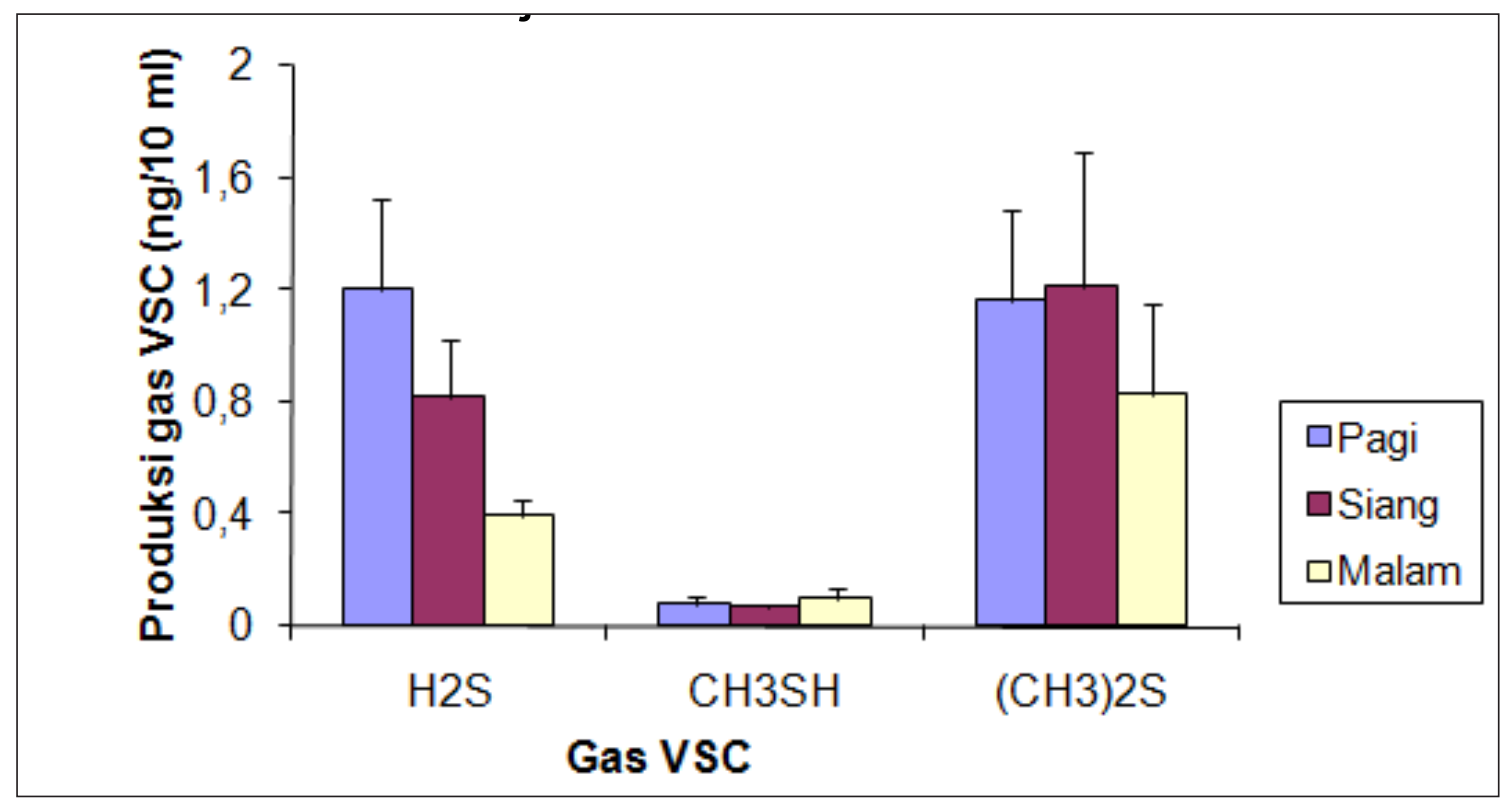

Gambar 1. Rerata produk VSCs yang diukurpada waktu pagi, siang dan malam hari (satuan $\mathrm{ng} / 10 \mathrm{ml}$ ). 
0,075 $\mathrm{ng} / 10 \mathrm{ml}$, siang hari $0,068 \mathrm{ng} / 10 \mathrm{ml}$, dan malam hari diketahui sebesar $0,099 \mathrm{ng} / 10 \mathrm{ml}$. Hasil pengukuran kadar gas metil merkaptan tertinggi terlihat pada malam hari. Selanjutnya, hasil pengukuran rerata kadar gas dimetil sulfide $\left(\left[\mathrm{CH}_{3}\right]_{2} \mathrm{~S}\right)$ pada pagi hari menunjukkan angka $1,166 \mathrm{ng} / 10 \mathrm{ml}$, siang hari $1,216 \mathrm{ng} / 10 \mathrm{ml}$, dan malam hari 0,830 $\mathrm{ng} / 10 \mathrm{ml}$. Hasil pengukuran tersebut menunjukkan bahwa kadar gas $\left[\mathrm{CH}_{3}\right]_{2} \mathrm{~S}$ tertinggi terjadi pada siang hari. Berdasarkan hasil pengukuran kadar VSC oral secara keseluruhan dimungkinkan adanya pengaruh waktu pengukuran (circadian) terhadap produkproduk gas VSC.

Analisis statistik pengaruh ritma circadian terhadap produk VSC oral diketahui dari Tabel1.

Hasil analisis statistic Tabel 1 menunjukkan adanya perbedaan yang sangat bermakna antara ritma circadian dan produk gas VSC $(\mathrm{P}=0.000)$. Dengan adanya perbedaan tersebut maka analisis dilanjutkan dengan uji post-hoc LSD dengan derajat kemaknaan 95\% seperti tampak pada Tabel 2.

Tabel 1. Hasil analisis statistik Anava antara ritma circadian dan gas VSC

\begin{tabular}{lccccc}
\hline \multicolumn{1}{c}{ Source } & Type III Sum of Squares & df & Mean Square & F & Sig. \\
\hline Corrected Model & $50.859^{a}$ & 9 & 5.651 & 4.581 & .000 \\
Intercept & 34.117 & 1 & 34.117 & 27.658 & .000 \\
Gas & 50.859 & 9 & 5.651 & 4.581 & .000 \\
Error & 265.210 & 215 & 1.234 & & \\
Total & 412.802 & 225 & & & \\
Corrected Total & 316.069 & 224 & & & \\
\hline
\end{tabular}

a. R Squared $=, 161$ (Adjusted R Squared $=, 126$ )

Tabel 2. Analisis post hoc antara waktu (circadian) dan produk VSC oral

\begin{tabular}{lccccc}
\hline & $\mathrm{H}_{2} \mathrm{~S}$ pagi & $\mathrm{H}_{2} \mathrm{~S}$ siang & $\mathrm{H}_{2} \mathrm{~S}$ malam & $\mathrm{CH}_{3} \mathrm{SH}$ pagi & $\mathrm{CH}_{3} \mathrm{SH}$ siang \\
\hline $\mathrm{H}_{2} \mathrm{~S}$ pagi & & 0,173 & $0,008 * *$ & $0,000 * *$ & $0,000 * *$ \\
$\mathrm{H} \mathrm{S}_{2}$ siang & 0.173 & & 0,973 & 0,577 & 0,569 \\
$\mathrm{H}_{2} \mathrm{~S}$ malam & 0,080 & 0,973 & & 0,311 & 0,301 \\
$\mathrm{CH}_{3} \mathrm{SH}$ pagi & $0,008 * *$ & 0,577 & 0,311 & & 0,983 \\
$\mathrm{CH}_{3} \mathrm{SH}$ siang & $0,000 * *$ & 0,569 & 0,301 & 0,983 & \\
$\mathrm{CH}_{3} \mathrm{SH}$ malam & $0,000 * *$ & 0,605 & 0,305 & 0,938 & 0,921 \\
$\left(\mathrm{CH}_{3}\right)_{2} \mathrm{~S}$ pagi & 0,796 & 0,218 & $0,015 *$ & $0,001 * *$ & $0,001 * *$ \\
$\left(\mathrm{CH}_{3}\right)_{2} \mathrm{~S}$ siang & 0,952 & 0,163 & $0,006 * *$ & $0,000 * *$ & $0,000 * *$ \\
$\left(\mathrm{CH}_{3}\right)_{2} \mathrm{~S}$ malam & 0,189 & 0,495 & 0,166 & $0,017 *$ & $0,016 *$ \\
\hline
\end{tabular}




\begin{tabular}{|c|c|c|c|c|}
\hline & $\mathrm{CH}_{3} \mathrm{SH}$ malam & $\left(\mathrm{CH}_{3}\right)_{2} \mathrm{~S}$ pagi & $\left(\mathrm{CH}_{3}\right)_{2} \mathrm{~S}$ siang & $\left(\mathrm{CH}_{3}\right)_{2} \mathrm{~S}$ malam \\
\hline $\mathrm{H}_{2} \mathrm{~S}$ pagi & $0,000 * *$ & 0,796 & 0,952 & 0,189 \\
\hline $\mathrm{H}_{2} \mathrm{~S}$ siang & 0,605 & 0,218 & 0,169 & 0,495 \\
\hline $\mathrm{H}_{2} \mathrm{~S}$ malam & 0,350 & $0,015 *$ & $0,006 * *$ & 0,166 \\
\hline $\mathrm{CH}_{3} \mathrm{SH}$ pagi & 0,938 & $0,001 * *$ & $0,000 * *$ & $0,017 *$ \\
\hline $\mathrm{CH}_{3} \mathrm{SH}$ siang & 0,921 & $0,001 * *$ & $0,000 * *$ & $0,016 *$ \\
\hline $\mathrm{CH}_{3} \mathrm{SH}$ malam & & $0,001 * *$ & $0,000 * *$ & $0,021 *$ \\
\hline$\left(\mathrm{CH}_{3}\right)_{2} \mathrm{~S}$ pagi & $0,001 * *$ & & 0,750 & 0,286 \\
\hline$\left(\mathrm{CH}_{3}\right)_{2} \mathrm{~S}$ siang & $0,000 * *$ & 0,750 & & 0,170 \\
\hline$\left(\mathrm{CH}_{3}\right)_{2} \mathrm{~S}$ malam & $0,021 *$ & 0,286 & 0,170 & \\
\hline
\end{tabular}

Keterangan : * bermakna $\mathrm{P}=0,05$, dan ** sangat bermakna $\mathrm{P}=0,01$

Hubungan yang kuat antara ritma circadian dan produk VSC oral diketahui melalui uji korelasi Pearson sebesar $r=0,738$.

\section{PEMBAHASAN}

Halitosis merupakan suatu kondisi yang memerlukan perhatian profesional dari tenaga kesehatan gigi. Pertumbuhan produk komersial anti bau mulut sebagai bukti meningkatnya jumlah populasi yang perhatian dengan kondisi halitosis. ${ }^{18}$ Halitosis atau disebut malodor dihasilkan dari bahanbahan produk metabolisme asam amino bakteri seperti food debris, deskuamasi sel mukosa oral, dan leukosit yang dapat berakumulasi di oral yang dapat menimbulkan bau tidak sedap. Metabolit yang dihasilkan tersebut termasuk VSC, indol, skatol, derivat amin dan amonia yang merupakan penyebab utama halitosis. Saat ini para peneliti memfokuskan penelitiannya pada teknik pengukuran kadar gas VSC menggunakan monitoring gas kromatografi dan sulfida yang masih sangat sedikit dilaporkan. ${ }^{20}$ Pengukuran kadar halitosis melalui deteksi gas VSC pada penelitian ini menggunakan alat portable OralChroma (Abilit, Japan) yang merupakan alat monitor gas kromatografi dan sulfida yang sensitif mengukur gas hidrogen sulfida, metil merkaptan dan dimetil sulfida. Ikawa $\mathrm{dk},{ }^{11}$ melaporkan hasil ciptaan dan penggunaan gas kromatografi (Breathtronk,
Japan) yang capable, reliable dan visible dalam mengukur kadar halitosis. Dalam penelitiannya dilakukan pengukuran gas VSC tidak hanya di laboratorium tetapi juga di rumah subyek penelitian. Hasil penelitian dilaporkan bahwa perubahan kadar gas VSC sangat berhubungan dengan asupan makanan dan menyikat gigi.

Hasil pengukuran tiga gas utama VSC oral yang dilakukan pada waktu pagi, siang dan malam hari pada penelitian ini menunjukkan bahwa kadar tertinggi gas hidrogen sulfida $\left(\mathrm{H}_{2} \mathrm{~S}\right)$ terdeteksi pada pagi hari, kadar gas metil merkaptan $\left(\mathrm{CH}_{3} \mathrm{SH}\right)$ tertinggi diketahui pada malam hari, sedangkan kadar tertinggi gas dimetil sulfida $\left(\left[\mathrm{CH}_{3}\right]_{2} \mathrm{~S}\right)$ pada siang hari. Hasil data tersebut menegaskan bahwa pengukuran produk gas VSC oral dipengaruhi oleh ritma circadian. Selain itu, perbedaan kadar VSC oral tertinggi pada waktu tertentu menunjukkan jenis mikroba oral tertentu yang tumbuh lebih banyak. Data tersebut sesuai dengan laporan Thines dan Harmon ${ }^{17}$ bahwa ritma circadian mempunyai pengaruh terhadap aktivitas mikrobiologi oral. Kadar tertinggi gas $\mathrm{H}_{2} \mathrm{~S}$ yang terjadi pada pagi hari menunjukkan tingginya aktivitas bakteri Veillonella, Actinomyces, Provotella ${ }^{21}$, bakteri Peptosteptococcus anaerobius, Micros prevotti, Eubacterium limosum, Bacteroides sp., Centipedia periodontii, dan Selenomonas artermidis. ${ }^{22} \mathrm{Kadar}$ gas $\mathrm{CH}_{3} \mathrm{SH}$ tertinggi yang terjadi pada malam hari menunjukkan tingginya 
aktivitas bakteri Archaebacteria, Halobacterium, Sulfolobus, Pyrodictium, Methanomicrobiumdan golongan bakteri metanogen lainnya, ${ }^{23}$ sedangkan kadar gas $\left[\mathrm{CH}_{3}\right]_{2} \mathrm{~S}$ tertinggi diketahui pada siang hari mengindikasikan bahwa aktivas bakteri grup Pseudomonas, Flavobacteria, dan enis enterobacteria tinggi. ${ }^{24}$ Data statistik menggunakan uji korelasi Pearson menunjukkan hubungan yang kuat antara pengukuran kadar produk VSC oral dengan ritma circadian $(r=0,738)$.

Faktor yang mempengaruhi tingginya kadar halitosis pada subyek penelitian yang digunakan dalam penelitian ini antara lain subyek perokok, jenis kelamin, kondisi sitemik (menstruasi, konsumsi obat), oral hygiene dan makanan-minuman yang dikonsumsi. Perokok mempunyai kadar VSC yang tinggi dan rokok dikategorikan sebagai faktor ekstrinsik penyebab halitosis. ${ }^{19}$ Kondisi sistemik subyek seperti kondisi menstruasi dan konsumsi obatobatan juga menyebabkan tingginya kadar VSC oral. Perbedaan tingkat kebersihan mulut subyek turut pula menentukan tinggi rendahnya kadar gas VSC. Berdasarkan semua data hasil penelitian dan target yang dicapai dalam penelitian ini diketahui bahwa permasalahan penelitian sudah terjawab.

\section{KESIMPULAN}

Berdasarkan hasil penelitian dan pembahasan yang telah diuraikan di atas dapat diambil kesimpulan sebagai berikut: 1) Ritma circadian berpengaruh terhadap produksi volatile sulfur compound oral. Produksi gas $\mathrm{H}_{2} \mathrm{~S}$ dan $\left(\mathrm{CH}_{3}\right)_{2} \mathrm{~S}$ berbeda antara pagi, siang dan malam, sedangkan produksi gas $\mathrm{CH}_{3} \mathrm{SH}$ berbeda hanya pengukuran siang dan malam hari; 2) Produksi gas $\mathrm{H}_{2} \mathrm{~S}$ tertinggi pada pagi hari, gas $\mathrm{CH}_{3} \mathrm{SH}$ pada malam hari, dan gas $\left(\mathrm{CH}_{3}\right)_{2} \mathrm{~S}$ pada siang hari.

\section{DAFTAR PUSTAKA}

1. Loesche WJ, Kazor C. Microbiology and treatment of halitosis. Periodontol. 2001; 28: 256-79.

2. Scully C, Porter S, Greenman J. What to do about halitosis. BMJ. 1994; 308: 217-8.

3. Tangerman A. Halitosis in medicine: a review. Int Dent J. 2002; 3: 201-6.
4. Lee SS, Zhang WU, Li Y. Halitosis update: a review of causes, diagnoses, and treatments. J Calif Dent Assoc. 2007; 35: 258-60, 264-8.

5. Miyazaki H, Sakao S, Katoh Y, Takehara T. Correlation between volatile sulphur compounds and certain oralhealth measurements in the general population. J Periodontol. 1995; 66: 679-84.

6. Yaegaki K, Coil JM. Genuine halitosis, pseudohalitosis, and halitophobia: classification, diagnosis, and treatment.Compend Contin Educ Dent. 2000; (10A): 880-6, 888-9.

7. Tsai CC, Chou HH, Wu TL, Yang YH, Ho KY, Wu YM. The levels of volatile sulfur compounds in mouth air from patients with chronic periodontitis. J Periodontal Res. 2008; 43(2): 186-93.

8. Oho T, Yoshida Y, Shimazaki Y, Yamashita Y, Koga T. Characteristicsof patients complaining of halitosis and the usefulnessof gas chromatography for diagnosing halitosis. Oral Surg OralMed Oral Pathol Oral Radiol Endod. 2001; 91: 531-4.

9. Porter SR, Scully C. Oral malodor (halitosis). BMJ. 2006; 333(7569): 632-5.

10. Ueda H, Sato Y, Nakayama T, Hashimoto M, Honda S. Clinical significance of the oral ammonia analyzer ATTAIN for halitosis treatment. In: Abstracts of the 5th International Conference on Breath Odor. Tel Aviv: International Society for Breath Odor Research. 2001; H. 44.

11. Ikawa K, Iwakura M, Washio J, Kusano A, Tanda $\mathrm{N}$, Koseki T. Circadian changes of volatile sulfur compounda measured by Breathtronk. Intl Congress Series. 2005; 1284: 427-30.

12. ZivkovicB. Circadian Quackery. A Blog Around the Clock. Retrieved. 2008, diunduh 23-2-2010.

13. Itoh K, Masumori S, Nakajima M, Hayashi $M$, Sakakibara H, Shimoi K. Differences in micronucleus induction in peripheral blood reticulocytes of mice exposed to $\mathrm{N}$-ethyl-N-nitrosurea at light and dark dosing times. J Toxicol Sci. 2012; 37(2): 427-30.

14. Curtis AM, Cheng Y, Kapoor S, Reilly D, Price TS, Fitzgerald GA. Circadian variation of blood pressure and the vascular response to asynchronous stress. PNAS. 2007; 104: 3450-5. 
15. Voogel AJ, Koopman MC, Hart AA, van Montfrans GA, Arisz L. Circadian rhythms in systemic hemodynamics and renal function in healthy subjects and patients with nephrotic syndrome.Kidney Int . 2001; 59(5):1873-80.

16. Hasting M, O'Neil JS, Maywood ES. Circadian clock: regulators of endocrine and metabolic rhythms. J Endocrin. 2012; 213(1): 1-5.

17. Thines B, Harmon FG. Four easy pieces: mechanisms underlying circadian regulation of growth and development. Curr Opin Plant Biol. 2011; 14(1): 31-7.

18. Suzuki N, Yoneda M, Naito T, Iwamoto T, Hirofuji T. Relationship between halitosis and psychologic status. Oral Surg Oral Med Pathol Oral Radiol Endod. 2008; 106: 542-7.

19. Al-Ansari JM, Boodai H, Al-Sumait N, Al-Khabbaz AK, Al-Shammari K, Salako N. Factors associated with self-reported halitosisi in Kuwaiti patients. J Dent. 2006; 34: 444-9.
20. Amano A, Yoshida Y, Oho T, Koga T. Monitoring ammonia to assess halitosis. Oral Surg Oral Med Oral Pathol Oral Radiol Endod. 2002; 94(6): 692-6.

21. Washio J, Sato T, Koseki T, Takahashi N. Hydrogen sulfide-producing bacteria in tongue biofilm and their relationship with oral malodour. J Med Microbiol. 2005; 54: 889-95.

22. Krespi YP, Shrime MG, Kacker. A. The relationship between oral malodor and volatile sulfur compounds-producing bacteri, Otolaryngol Head Neck Surg. 2006; 135(5): 671-6.

23. Pablo J. Metanogenesis. Kuliah Biologi. http:// matakuliahbiologi.blogspot.com/2012/06/ metanogenesis.html. Diunduh Rabu, 14 November 2012.

24. Lucas DD, Prinn RG. Parametric sensitivity and uncertainty analysis of dimethylsulfide oxidation in the clear-sky remote marine boundary layer. Atmospheric Chem Phy. 2005; 5(6): 1505-1525. 